\title{
Dystrakcja i obciążenie poznawcze a skuteczność tłumienia myśli
}

\section{The role of distraction and cognitive load in thought suppression}

\begin{abstract}
Despite general agreement that successful thought suppression depends on distraction and cognitive load, we do not know how exactly those factors affect mental control. This is due to terminological confusion, on the one hand, and some mutually incompatible experimental results, on the other. The present article is an attempt to specify the impact of distraction and cognitive control on the effectiveness of thought suppression. On the proposed account, distraction and cognitive load should be considered jointly because arguably every act of distraction produces some cognitive load. Two types of distraction are also distinguished: one engaging mainly the direct-access region postulated by Oberauer and the other involving cognitive control resources. Distraction of the former kind should improve thought suppression whereas distraction of the latter kind should inhibit it.
\end{abstract}

Keywords: thought suppression, distraction, cognitive load, attention, mental control

Tłumienie myśli można zdefiniować jako wolicjonalną czynność umysłową nakierowaną na niedopuszczenie wybranych treści do świadomości. Jest ono jednym z przejawów samoregulacji poznawczej i jako takie wiąże się ściśle z zagadnieniem funkcji zarządczych [Nigg, 2017]. Pytania o skuteczność i konsekwencje tłumienia są ważne z kilku powodów. Po pierwsze, u znacznej większości ludzi regularnie pojawiają się niechciane treści umysłowe [Rachman, de Silva, 1978]. Po drugie, myśli intruzywne współtworzą obraz kliniczny wielu zaburzeń psychicznych, a ich tłumienie może odgrywać istotną rolę w genezie lub przebiegu tych zaburzeń [Magee, Harden, Teachman, 2012; Najmi, Wegner, 2008; Purdon, 1999]. Po trzecie, tłumienie myśli jest jedną z form samokontroli mentalnej, o której właściwościach nadal wiadomo zbyt mało.

Czynnikami, które zdają się wpływać na skuteczność tłumienia myśli, są obciążenie poznawcze i dystrakcja. W artykule analizuję je łącznie, jako zmienne bardzo ściśle ze sobą związane. Postuluję odróżnienie form dystrakcji obciążającej zasoby poznawcze w sposób, który ułatwia blokowanie niechcianych myśli oraz form dystrakcji upośledzających tę czynność. 


\section{Wpływ dystrakcji na skuteczność tłumienia myśli w świetle teorii paradoksalnych procesów kontroli umysłu Wegnera}

Trudność w ustaleniu, czy dystrakcja sprzyja tłumieniu, czy mu przeszkadza, wynika między innymi z posługiwania się terminem „dystrakcja” w odmiennych kontekstach. Dystrakcja wiąże się z przekierowaniem uwagi z jednego bodźca na inny lub z relokacją zasobów poznawczych. $\mathrm{W}$ moim rozumieniu jest to pojęcie relatywne. Gdy przekierowujemy uwagę z bodźca A na bodziec B, ten ostatni staje się dystraktorem względem bodźca $\mathrm{A}$. Kiedy zasoby poznawcze, dzięki którym realizowano proces $\mathrm{A}$, są inwestowane $\mathrm{w}$ realizację procesu $\mathrm{B}$, proces $\mathrm{B}$ można uznać za przyczynę dystrakcji procesu A. W artykule Daniela Wegnera Ironic processes of mental control [1994], czyli w jednej z najważniejszych prac dotyczących tłumienia myśli, pojęcie dystrakcji używane jest w dwóch różnych znaczeniach.

W pracy tej Wegner przedstawia teorię paradoksalnych procesów kontroli umysłu. Dystrakcja jest tu warunkiem sine qua non tłumienia myśli. Według autora tłumienie dokonuje się dzięki działaniu dwóch procesów: procesu poszukiwania dystraktorów (zwanego też procesem operacyjnym) oraz procesu monitorującego występowanie unikanej treści. Działanie pierwszego z procesów polega na znajdowaniu treści innych niż ta niechciana i wypełnianiu nimi umysłu. Autor pisze:

Proces operacyjny doprowadza do oczekiwanej zmiany dzięki wypełnianiu umysłu myślami i wrażeniami, które są kluczowe dla pożądanego stanu. (...) W przypadku, gdy celem jest stłumienie myśli, proces operacyjny (...) szuka treści (...) innych niż ta unikana. Poprzez wyszukiwanie dystraktorów zapewniana jest kontrola umysłowa [Wegner, 1994, s. 35-37].

Proces monitorujący natomiast na bieżąco sprawdza, czy osiągnięty został cel kontroli umysłowej, a więc czy ryzyko pojawienia się tłumionej myśli w świadomości nie jest duże. Jeśli wykryje niechcianą treść, daje impuls procesowi operacyjnemu do wznowienia działania. Ten ostatni proces - w odróżnieniu od procesu monitorującego - jest bowiem kontrolowany świadomie i wymaga relatywnie wielu zasobów, stąd też jego działanie nie jest kontynuowane przez cały czas tłumienia myśli. Paradoksalne następstwa tłumienia pojawiają się, gdy nie wystarcza zasobów na poprawne funkcjonowanie procesu operacyjnego. Wtedy uwidaczniają się skutki uboczne procesu monitorującego $\mathrm{w}$ postaci szczególnego uwrażliwienia na wyszukiwaną treść, które nie jest równoważone przez dystrakcję. Wegner charakteryzuje to następująco:

(...) proces operacyjny zaczyna pracować, absorbując uwagę osoby. Taki stan może trwać bez końca pod warunkiem, że uwaga nie będzie pochłaniana przez inne zadanie oraz że proces monitorujący nie wykryje niepożądanych treści. (...) Różnego rodzaju dystraktory, związane $z$ bodźcami wewnętrznymi lub zewnętrznymi, mogą pochłaniać zasoby umysłowe, co ograniczy ilość zasobów zasilających proces operacyjny i zmniejszy jego efektywność. (...) Każdy rodzaj ograniczenia pojemności umysłowej (mental capacity) - czy to wynikający z czynników sytuacyjnych, czy też z aktualnego stanu osoby - w większym stopniu upośledzi proces operacyjny niż monitorujący. (...) Wszystko, 
co odciąga uwagę osoby od kontroli umysłowej, będzie utrudniać działanie procesu operacyjnego, a $\mathrm{w}$ konsekwencji wzmocni efekty związane $\mathrm{z}$ pracą procesu monitorującego. (...) teoria przewiduje, że (a) dodatkowe obciążenie spowoduje osłabienie efektów działania procesu operacyjnego w stosunku do efektów paradoksalnego monitorowania oraz że (b) w konsekwencji ujawnią się efekty paradoksalne. Wraz ze wzrostem obciążenia opisane zjawiska powinny się nasilać, aż w końcu przy ekstremalnych poziomach obciążenia efekty paradoksalne osiągną rozmiar zbliżony do rezultatów obserwowanych w sytuacji, w której celem osoby jest uzyskanie tego rodzaju efektów, nie zaś uniknięcie ich [Wegner, 1994, s. 38-40].

Analizując teorię Wegnera lub nawet tylko spoglądając na dwa zamieszczone cytaty, można zauważyć, że rozpatruje on dystrakcję w dwóch kontekstach. W pierwszym rozumie ją jako odwrócenie uwagi od niechcianych treści. W drugim jako coś, co pochłania zasoby potrzebne do działania procesu operacyjnego. Dystrakcja od niechcianych treści jest nieodzownym elementem tłumienia myśli, dystrakcja kolidująca z procesem operacyjnym prowadzi do paradoksalnych następstw kontroli umysłu.

Odróżnienie przejawów obu rodzajów dystrakcji, a więc stwierdzenie, kiedy mamy do czynienia z dystrakcją od niechcianych myśli, a kiedy z dystrakcją kolidującą z procesem operacyjnym, mogłoby znaleźć zastosowania praktyczne. Można by bowiem odróżnić aktywności wspierające i utrudniające tłumienie myśli.

\section{Procesy kontroli umysłowej a funkcje zarządcze}

Zanim przejdę do omawiania, jak różne rodzaje dystrakcji wpływają na skuteczność tłumienia myśli, zatrzymam się przez chwilę, by dookreślić, czym są postulowane przez Wegnera procesy kontroli umysłowej, w szczególności proces operacyjny. Podczas gdy proces monitorujący wydaje się działać na zasadzie wykrywania i reagowania na konkretny sygnał czy też treść umysłową, proces operacyjny jest bardziej złożony. W celu lepszej jego charakterystyki odniosę się do zagadnienia funkcji zarządczych. Naomi Friedman i Akira Miyake [2017] definiują je jako funkcje poznawcze wyższego rzędu, wpływające na procesy niższego rzędu, umożliwiając regulację myśli i zachowań w taki sposób, by były one zgodne z obranymi celami. Joel Nigg [2017] w pracy porządkującej terminologię związaną z samoregulacją podobnie charakteryzuje funkcje zarządcze - jako procesy odgórne, pozwalające na kontrolę sfery emocjonalnej, behawioralnej i poznawczej z uwagi na przyjęty cel.

Proces operacyjny powinien zatem zostać uznany za funkcję zarządczą lub za proces realizowany przez funkcje zarządcze. Przypomnijmy, że w przypadku tłumienia myśli proces ten zajmuje się wyszukiwaniem treści innych niż niechciana oraz „wypełnianiem umysłu” takimi treściami [Wegner, 1994]. Teoria paradoksalnych procesów kontroli umysłowej nie opisuje, w jaki sposób zadania te są wykonywane. Proces operacyjny może działać na podobnej zasadzie jak proces aktualizowania reprezentacji umysłowych w pamięci roboczej. Ten ostatni - obok hamowania i przerzutności - jest jednym z najczęściej badanych komponentów funkcji zarządczych [Friedman i in., 
2008]. Jego istotą jest zastępowanie w pamięci roboczej pewnych informacji innymi oraz podtrzymywanie aktywizacji wybranych informacji [Friedman, Miyake, 2017].

Istotne dla działania procesu operacyjnego powinno być również podtrzymywanie reprezentacji celu, jakim jest unikanie wybranej treści umysłowej oraz wpływanie na zachodzące procesy umysłowe, tak by służyły one wyznaczonemu celowi. W świetle badań Friedman i współpracowników [2008] są to funkcje generalnie wykorzystywane w zadaniach mierzących funkcje zarządcze niezależnie od tego, do pomiaru jakich specyficznych procesów zadania te zostały zaprojektowane. Podtrzymywanie i zarządzanie reprezentacją celu autorzy uważają za domenę tak zwanego wspólnego czynnika funkcji zarządczych, wykrytego w toku analizy zmiennych utajonych. Czynnik ten wiązał się ze wspólną zmiennością wyników we wszystkich dziewięciu zadaniach użytych w eksperymencie do pomiaru funkcji zarządczych (po trzy zadania mierzące sprawność hamowania, przerzutności i aktualizacji reprezentacji w pamięci roboczej).

W badaniu wykryto jeszcze dwie zmienne utajone: przerzutność i aktualizację reprezentacji w pamięci roboczej. Każda $\mathrm{z}$ nich wiązała się ze wspólną wariancją wyników w obrębie zadań służących pomiarowi tych funkcji, która to wariancja nie została uchwycona przez czynnik wspólny. Co ciekawe, nie ujawniła się zmienna utajona hamowania. Autorzy proponują dwie interpretacje takiego wyniku. Może on wskazywać, że mechanizmem leżącym u podłoża czynnika wspólnego jest właśnie hamowanie. Sugerowanym przez badaczy wyjaśnieniem jest jednak, że czynnik wspólny - jak wcześniej wspomniano - wiąże się z podtrzymywaniem i zarządzaniem celem, a efekt „hamowania” dystrakcji czy niepożądanych reakcji jest osiągany dzięki temu, że w rywalizacji poszczególnych reprezentacji zwycięża ta zgodna z aktywizowanym celem.

W efekcie, mimo że pojawia się naturalna skłonność do łączenia procesu operacyjnego z mechanizmem hamowania, sugeruję ostrożność. Nade wszystko Wegner, opisując proces operacyjny, nigdy nie odwoływał się do hamowania. Nie robił tego w odróżnieniu od wielu badaczy tłumienia myśli, którzy wyniki swoich badań wyjaśniali właśnie mechanizmem hamowania niechcianych treści. Przykładowo Michael Anderson i Collin Green [2001], wzorując się na paradygmacie go/no-go - służącym do pomiaru umiejętności hamowania czy też powstrzymywania się od przemożnych a niepożądanych reakcji motorycznych, stworzyli paradygmat „myśl/nie myśl” (think/no-think) do badania zdolności powstrzymywania niechcianych myśli. Wyniki w tym paradygmacie systematycznie pokazują, że powstrzymywane myśli są wręcz zapominane, co tłumaczone jest wyhamowaniem ich aktywizacji [Anderson, Huddleston, 2012; Anderson, Levy, 2009; Levy, Anderson, 2008]. Badania w paradygmacie „myśl/nie myśl” przynoszą odmienne rezultaty niż badania w Wegnerowskim paradygmacie „białego niedźwiedzia” [Wegner, Schneider, Carter, White, 1987], wskazującym na paradoksalne efekty tłumienia myśli [Abramowitz, Tolin, Street, 2001; Rassin, 2005; Wegner, 2009; Wenzlaff, Wegner, 2000]. Teoria paradoksalnych procesów kontroli umysłowej powstała między innymi, by wyjaśnić wyniki badań w ostatnim z paradygmatów. Badania te jednak świadczą o wzroście - a nie spadku - aktywizacji tłumionych treści, brakuje więc przestrzeni na nawiązanie do mechanizmu hamowania. 


\section{Zróżnicowany wpływ odmiennych rodzajów obciążenia poznawczego na skuteczność tłumienia myśli. Dystrakcja wspomagająca i utrudniająca tłumienie myśli}

Wcześniej wyodrębniłam dwa rodzaje dystrakcji, które mogą wystąpić podczas tłumienia myśli. Pierwszy to dystrakcja od niechcianej treści, związana ze skupieniem uwagi na innych, wewnętrznych lub zewnętrznych bodźcach. Drugi to dystrakcja zakłócająca proces operacyjny, związana z odbieraniem zasobów potrzebnych do prawidłowego funkcjonowania tego procesu. Ujmując to inaczej, podziału na wymienione dwa typy dystrakcji można dokonać ze względu na kryterium wykorzystywanych zasobów.

W psychologii poznawczej powszechnie akceptowany jest pogląd, że przetwarzanie informacji przez umysł wymaga pewnej ilości limitowanych zasobów [Nęcka, Orzechowski, Szymura, 2006, s. 25]. Przykładowo, ograniczona wydolność aparatu poznawczego człowieka to kluczowe założenie klasycznego zasobowego modelu uwagi Kahnemana [Śpiewak, 2013]. Postulat ten był weryfikowany w ramach tak zwanej metody zadań podwójnych, polegającej na zaangażowaniu uczestnika eksperymentu w wykonywanie dwóch zadań w tym samym czasie [Norman, Bobrow, 1975]. Wiele badań wykorzystujących tę metodę wykazało, że efektywność jednoczesnego wykonania dwóch zadań jest niższa, niż kiedy zadania te wykonywane są osobno. Takie wyniki interpretowano jako dowód, że zadania równoległe konkurują o zasoby z tej samej puli [Śpiewak, 2013].

Metafora zasobowa nie jest wystarczająco dookreślona. Otwarte pozostaje między innymi pytanie o liczbę rezerwuarów zasobów [Śpiewak, 2013]. Pojawiły się prace wskazujące na istnienie wielu takich rezerwuarów. Wykazano na przykład, że wielkość wzajemnej interferencji między zadaniami zależy od tego, którego etapu przetwarzania informacji zadania dotyczą. Wyniki tych badań świadczą o oddzielnej puli zasobów związanej z przetwarzaniem na etapie kodowania i centralnego przetwarzania i oddzielnej związanej z etapem wyboru reakcji [Wickens, Kessel, 1980]. Interferencja okazała się też zależna od modalności bodźców użytych w zadaniach równoległych. Wyższą interferencję zaobserwowano w przypadku, gdy w dwóch zadaniach wykorzystywano bodźce z tej samej modalności niż w przypadku bodźców z różnych modalności [Duncan, Martens, Ward, 1997] ${ }^{1}$.

Odróżniając dwa typy dystrakcji towarzyszącej tłumieniu myśli, zakładam istnienie oddzielnych rezerwuarów zasobów poznawczych. Przewiduję, że różne typy dystrakcji wiążą się z obciążeniem zasobów innego rodzaju. Od rodzaju generowanego

${ }^{1}$ Istnieje wiele innych kwestii związanych $\mathrm{z}$ metaforą zasobową, które wymagają dalszej eksploracji. Powstały alternatywne - pozazasobowe - wyjaśnienia efektów obserwowanych $\mathrm{w}$ badaniach z użyciem metody zadań podwójnych. Postulują one na przykład, że za efekty te odpowiada obniżenie jakości prezentowania danych lub że powstały one jako pokłosie zakłócania wykonania jednego zadania przez drugie z uwagi na - między innymi - wyhamowanie treści irrelewantnych $\mathrm{w}$ kontekście jednego zadania, a istotnych $\mathrm{w}$ zadaniu drugim. Wyjaśnienia zasobowe i pozazasobowe nie muszą się przy tym wykluczać. Dodatkowo rozumienie metafory zasobowej może zostać pogłębione poprzez analizę badań nad konsekwencjami, jakie ma wykonanie jednego zadania angażującego wysiłek poznawczy na następujące po nim drugie zadanie tego typu [Śpiewak, 2013]. 
przez dystrakcję obciążenia poznawczego powinien zależeć jej wpływ na skuteczność tłumienia myśli.

Dystrakcja pochłaniająca zasoby pozwalające na myślenie o czymś innym niż niechciana treść powinna wspierać tłumienie. Dystrakcja wykorzystująca zasoby potrzebne do funkcjonowania procesu operacyjnego prawdopodobnie będzie utrudniać blokowanie niechcianych myśli. Jest to przewidywanie poniekąd niezgodne z teorią Wegnera, która postuluje liniowy związek między powodzeniem tłumienia a obciążeniem poznawczym, zakładając, że im większe obciążenie, tym gorzej funkcjonuje proces operacyjny, przez co tłumienie myśli staje się bardziej problematyczne.

Przewidywanie, że różne rodzaje obciążenia poznawczego będą miały inny wpływ na skuteczność tłumienia myśli, zostało zainspirowane teorią obciążenia uwagi selektywnej i kontroli poznawczej [Lavie, Hirst, de Fockert, Viding, 2004] oraz badaniami potwierdzającymi tę teorię [m.in. Konstantinou, Beal, King, Lavie, 2014; Lavie, 2010]. Autorzy teorii, dokonując przeglądu badań nad uwagą selektywną, zauważyli, że interferujące działanie dystraktorów można wzmocnić lub osłabić w zależności od tego, jaki rodzaj obciążenia poznawczego zostanie nałożony na uczestnika eksperymentu. Kiedy uczestnicy mieli selekcjonować bodźce w warunkach znacznego obciążenia percepcyjnego (bodziec znajdował się w otoczeniu wielu dystraktorów), interferencja wywołana obecnością dystraktorów była mniejsza niż w warunkach małego obciążenia percepcyjnego (bodziec znajdował się w otoczeniu pojedynczych dystraktorów). Odpowiedzialny był za to bierny mechanizm selekcji percepcyjnej: ze względu na brak zasobów potrzebnych do spostrzeżenia całej sceny percepcyjnej dostrzegano jedynie bodźce istotne, ignorując przy tym dystraktory. Kiedy obciążenie percepcyjne było niewielkie, dystraktory przetwarzano głębiej, co zakłócało wykonanie zadania.

Niemniej także w warunkach małego obciążenia percepcyjnego uczestnikom udawało się generować prawidłowe reakcje. Autorzy tłumaczą to działaniem mechanizmów kontroli poznawczej, która podporządkowuje zachowania wyznaczonemu celowi, zapobiegając nadmiernej reaktywności. Obciążenie funkcji kontrolnych może upośledzić wykonanie zadania selekcyjnego. Inaczej niż w przypadku obciążenia percepcyjnego odebranie zasobów przekłada się tutaj na słabszą selekcję reakcji.

Zagadnienie tłumienia myśli można rozpatrywać w kontekście przedstawionej teorii. Osoba tłumiąca myśli dokonuje specyficznej selekcji treści umysłowych: odrzuca treść niepożądaną, akceptując wszelkie pozostałe. Zadanie to może być zrealizowane przez dwa mechanizmy analogiczne do tych postulowanych w teorii Lavie i współpracowników.

Odpowiednikiem mechanizmu selekcji percepcyjnej u Lavie jest bierny mechanizm selekcji myśli do uświadomienia. Według Klausa Oberauera [2006; Oberauer, Bialkova, 2009] uświadamiane są myśli, które wcześniej były na tyle zaktywizowane, że znalazły się w tak zwanym obszarze bezpośredniego dostępu. Obszar ten ma limitowaną pojemność. Gdy jest on zajęty przez dystraktory, tłumiona myśl nie ma szans dostać się do świadomości - tak jak w przypadku przeładowanej bodźcami sceny percepcyjnej bodźce irrelewantne nie mogą być spostrzeżone.

$\mathrm{Z}$ drugiej strony mamy do czynienia z procesami kontroli poznawczej. U Lavie kontrola poznawcza odpowiada za wyselekcjonowanie właściwej reakcji nawet wtedy, gdy bodźce irrelewantne zostaną spostrzeżone. W przypadku tłumienia procesy kon- 
trolne mogą sprzyjać uświadomieniu treści innych niż unikana poprzez wyszukiwanie dystraktorów i podtrzymywanie na nich uwagi - także po tym, gdy niepożądana treść zostanie uświadomiona. Zajęcie zasobów zasilających kontrolę poznawczą powinno mieć negatywny wpływ na skuteczność tłumienia myśli.

Taka perspektywa pozwala na dalsze doprecyzowanie podziału na dystrakcję wspomagającą i utrudniającą tłumienie myśli. Dystrakcja pierwszego rodzaju wiąże się z zajęciem obszaru bezpośredniego dostępu. Jest to dystrakcja związana $\mathrm{z}$ wielością wysoce zaktywizowanych treści umysłowych (ewentualnie z intensywnością ich aktywizacji). Przy dystrakcji drugiego rodzaju - dystrakcji utrudniającej tłumienie myśli - mamy natomiast do czynienia z zajęciem zasobów wykorzystywanych przez kontrolę poznawczą. Czynności dystrakcyjne tego typu, angażując funkcje zarządcze, będą poznawczo bardziej skomplikowane.

\section{Wpływ dystrakcji i obciążenia poznawczego na skuteczność tłumienia myśli - badania empiryczne}

Badania nad wpływem dystrakcji czy obciążenia poznawczego na skuteczność tłumienia myśli nie dają jednorodnych rezultatów. Być może odmienne wyniki dałoby się wytłumaczyć za pomocą hipotezy o zróżnicowanym oddziaływaniu dystrakcji na efektywność tłumienia myśli w zależności od rodzaju obciążonych zasobów.

Jest wiele badań świadczących o tym, że obciążenie poznawcze utrudnia tłumienie myśli i samokontrolę [m.in.: Nixon, Cain, Nehmy, Seymour, 2009; Nixon, Rackebrandt, 2016; Ward, Mann, 2000; Wegner, Erber, Zanakos, 1993; Wenzlaff, Bates, 2000; przegląd: Wegner, 2009]. Jednym z nich jest eksperyment Wegnera i Erbera [1992]. W badaniu uczestników podzielono na cztery grupy: dwie grupy eksperymentalne, w których tłumiono wyróżnione treści umysłowe, i dwie grupy kontrolne, w których koncentrowano się na tych treściach. W jednej grupie eksperymentalnej i w jednej kontrolnej uczestnicy wykonywali instrukcje $\mathrm{w}$ warunkach znacznego obciążenia poznawczego - mieli oni za zadanie zapamiętać dziewięciocyfrową liczbę. W pozostałych grupach do zapamiętania była liczba dwucyfrowa, co wiązało się z niewielkim obciążeniem poznawczym. Mierzono czas reakcji w zadaniu Stroopa, w którym część wyrazów stanowiły słowa odpowiadające treściom wyróżnionym. Okazało się, że wyróżnione treści były najbardziej dostępne w grupie tłumiącej w warunkach dużego obciążenia poznawczego. Obciążenie poznawcze wiązało się więc tutaj z paradoksalnymi efektami tłumienia myśli.

Dalszych dowodów na to, że obciążenie poznawcze utrudnia tłumienie, dostarczają badania w tak zwanym paradygmacie kierowanego zapominania [Conway, Harries, Noyes, Racsmány, Frankish, 2000; Macrae, Bodenhausen, Milne, Ford, 1997]. W badaniach w tym paradygmacie osoby uczą się dwóch list wyrazów. Część uczestników po przyswojeniu pierwszej listy otrzymuje polecenie, by zapomnieć o znajdujących się na niej wyrazach. Następnie prezentowana jest druga lista. Pozostali uczestnicy nie otrzymują instrukcji „zapomnij”. Badanie kończy się testem pamięci wyrazów $\mathrm{z}$ obu list. Rezultatem zastosowanej manipulacji eksperymentalnej jest zwykle gorsze pamiętanie słów z pierwszej listy przez uczestników, którzy starali się o tych słowach 
zapomnieć, niż przez uczestników z grupy kontrolnej. Pamięć listy drugiej jest natomiast lepsza w grupie eksperymentalnej niż w kontrolnej [Sheard, MacLeod, 2005].

Martin Conway wraz ze współpracownikami [2000] przeprowadził serię eksperymentów w paradygmacie kierowanego zapominania. W części z nich manipulowano wielkością obciążenia poznawczego nakładanego na uczestników podczas nauki drugiej listy (czyli podczas wykonywania instrukcji „zapomnij” w grupie eksperymentalnej). W jednym $\mathrm{z}$ badań równolegle do zapamiętywania wyrazów z drugiej listy uczestników poproszono o zliczanie samogłosek z tych wyrazów, tak by na koniec podać sumę wszystkich samogłosek. Osoby z grupy eksperymentalnej z obciążeniem poznawczym lepiej pamiętały listę pierwszą niż osoby z grupy eksperymentalnej bez obciążenia poznawczego. Innymi słowy, obciążenie utrudniało intencjonalne zapominanie. Niemniej w warunkach takiego obciążenia poznawczego w dalszym ciągu $\mathrm{w}$ grupie eksperymentalnej gorzej pamiętano listę pierwszą niż w grupie kontrolnej. Ten efekt zniknął, gdy dodatkową instrukcję liczenia samogłosek zastąpiono poleceniem pamiętania sześciocyfrowej liczby. W tych warunkach uczestnicy z grupy eksperymentalnej pamiętali lepiej listę pierwszą (czyli listę, którą mieli zapomnieć) niż listę drugą. Pamięć drugiej listy była też gorsza w tej grupie niż w grupie kontrolnej.

Jak wcześniej wspominano, wyniki współczesnych badań nad rolą dystrakcji i obciążenia poznawczego $w$ tłumieniu myśli nie są jednoznaczne. Dowodem na to jest badanie $\mathrm{w}$ paradygmacie kierowanego zapominania wskazujące, że obciążenie poznawcze może ułatwiać (czy wręcz umożliwić) tłumienie myśli. Należy odnotować, że $w$ badaniach $w$ tym paradygmacie zawsze obecne jest pewne obciążenie poznawcze podczas realizacji instrukcji „zapomnij”. Związane jest ono z wymogiem zapamiętywania kolejnej listy wyrazów. Gelfand i Bjork [1985, za: Bjork, Bjork, Anderson, 1998] w swoim eksperymencie stworzyli warunki bez jakiegokolwiek obciążenia poznawczego. Uczestnicy uczyli się jedynie listy pierwszej, po której w zależności od grupy otrzymali instrukcje „zapomnij” lub „pamiętaj”. Następnie pozostawiano ich w samotności do momentu testu pamięci. Nie odnotowano efektu kierowanego zapominania - pamięć wyrazów w obu grupach utrzymywała się na podobnym poziomie. Efekt nie pojawił się również wtedy, gdy podczas oczekiwania na test pamięci uczestnicy mieli dokonywać oceny prezentowanych przymiotników. Wystąpił dopiero, gdy po nauce pierwszej listy należało zapamiętać wyrazy z listy drugiej. W tym przypadku określone obciążenie poznawcze w postaci uczenia się nowego materiału było warunkiem powodzenia intencjonalnego zapominania.

Te wyniki korespondują z wynikami badania nad znaczeniem dystrakcji w tłumieniu, które przeprowadzono w paradygmacie „myśll/nie myśl” [Hertel, Calcaterra, 2005]. W pierwszym etapie badania uczestnicy uczyli się par wyrazów. W etapie drugim wielokrotnie prezentowano pierwszy wyraz z danej pary (wyraz-wskazówkę), a zadaniem uczestnika było - w zależności od instrukcji przyporządkowanej określonemu słowu - albo przypomnieć sobie drugi wyraz z pary, albo stłumić myśl o nim. Dodatkowo części uczestników podczas prób „nie myśl” prezentowano wyrazy-dystraktory, na których trzeba było skupić uwagę. Nie wszystkie wyrazy-wskazówki z pierwszego etapu pojawiły się w etapie „myśl/nie myśl”. W trzecim etapie uczestnicy podchodzili do testu pamięci, w którym mieli przywołać drugi wyraz z każdej pary uczonej na początku eksperymentu. 
Zazwyczaj w eksperymentach w paradygmacie „myśl/nie myśl” słowa, o których w etapie drugim należało nie myśleć, są gorzej pamiętane niż słowa, które w tym etapie trzeba było sobie przypomnieć, ale także niż słowa kontrolne, czyli takie, których wyrazy-wskazówki zupełnie nie pojawiły się w etapie „myśl/nie myśl” [Levy, Anderson, 2008]. W opisanym badaniu tylko uczestnicy, którym prezentowano wyrazy-dystraktory, gorzej pamiętali wyrazy tłumione niż kontrolne. W grupie bez dystrakcji nie odnotowano takiego efektu. Kolejne badania w paradygmacie „myśl/nie myśl” zazwyczaj potwierdzały, że dystrakcja tego typu wspomaga zapominanie niechcianych treści [Anderson, Huddleston, 2012].

Nawet wśród badań w paradygmacie „białego niedźwiedzia” [Wegner, Schneider, Carter, White, 1987] - gdzie większość eksperymentów świadczy o paradoksalnych skutkach tłumienia myśli [Abramowitz, Tolin, Street, 2001; Rassin, 2005; Wenzlaff, Wegner, 2000] - można odnaleźć dowody na skuteczność blokowania niechcianych treści, kiedy tłumieniu towarzyszy pewien rodzaj dystrakcji. Yi-Jen Lin i Frank Wicker [2007] przeprowadzili eksperyment $\mathrm{z}$ dwiema grupami tłumienia i dwiema grupami kontrolnymi. W jednej grupie tłumienia i w jednej grupie kontrolnej uczestników poproszono o wyobrażanie sobie własnej kuchni i jej opis na kartce. Pozostali uczestnicy nie otrzymali dodatkowego zadania. W rezultacie podczas etapu, w którym tłumiono myśli, osoby z grupy tłumiącej wykonujące zadanie dystrakcyjne doświadczyły mniej intruzji niż osoby z grupy tłumienia bez dystrakcji, a także niż osoby z grupy kontrolnej bez dystrakcji. Dwie ostatnie grupy nie różniły się od siebie pod względem liczby intruzji. Wydaje się więc, że tłumienie myśli było skuteczniejsze, kiedy uwaga osób została zaabsorbowana.

Podobne rezultaty uwidoczniły się $\mathrm{w}$ badaniu Juana V. Luciano i Salvadora S. Gonzáleza [2007], w którym tłumiono myśli awersyjne. Uczestnicy, którzy jednocześnie tłumili myśli i wyobrażali sobie wnętrze budynku uczelni, po etapie tłumienia rzadziej przypominali sobie o wyróżnionych treściach niż osoby z grupy swobodnego myślenia, w której nie podejmowano wcześniej prób blokowania tych treści. Nie odnotowano natomiast różnic między częstością wyróżnionych treści w grupie swobodnego myślenia i w grupie tłumienia bez dystrakcji.

\section{Dystrakcja i obciążenie poznawcze a tłumienie myśli - konkluzje i przyszłe badania}

Część badań wskazuje, że dystrakcja utrudnia tłumienie myśli, inne - że działa wspomagająco. Sprzeczne wyniki można spróbować wyjaśnić poprzez wyodrębnienie różnych form dystrakcji, tak jak to wyżej proponowano. Przywołane badania warto zanalizować pod kątem rodzaju występującej w nich dystrakcji: czy jest to dystrakcja powodująca zajęcie obszaru bezpośredniego dostępu, czy obciążająca funkcje zarządcze. Pierwsza forma dystrakcji hipotetycznie powinna pomagać w blokowaniu niechcianych treści, druga - blokowanie utrudniać. Zadania takie jak utrzymywanie w pamięci wielocyfrowych liczb lub wykonywanie obliczeń matematycznych równolegle do realizacji innych poleconych instrukcji (na przykład wykonywania zadania Stroopa lub nauki nowego materiału) prawdopodobnie znacznie obciążają procesy 
aktualizowania reprezentacji $\mathrm{w}$ pamięci roboczej oraz podtrzymywania reprezentacji celu, czyli funkcje zarządcze, które wyżej powiązałam z działaniem procesu operacyjnego. Jak się wydaje, wyobrażanie sobie dobrze znanych miejsc lub koncentracja na nowym materiale w mniejszym stopniu angażuje kontrolę poznawczą, za to zajmuje obszar bezpośredniego dostępu. By zweryfikować hipotezę o zróżnicowanym oddziaływaniu dystrakcji na tłumienie myśli w zależności od rodzaju obciążenia poznawczego $\mathrm{z}$ nią związanego, należałoby jednak przeprowadzić specjalnie $\mathrm{w}$ tym celu zaprojektowany eksperyment.

$\mathrm{W}$ takim eksperymencie trzeba by było starannie przemyśleć dobór zadania równoległego do tłumienia myśli. W przeciwnym wypadku narażamy się na możliwość wyciągnięcia mylących wniosków. Jeśli bowiem dwa procesy są zasilane innymi zasobami, prawdopodobnie nie ujawni się interferencja między zadaniami, która skądinąd powinna wystąpić, gdyby oba procesy korzystały z jednego rezerwuaru [Śpiewak, 2013]. W badaniu testującym przedstawioną hipotezę uczestnicy powinni tłumić myśli, wykonując równocześnie zadanie obciążające obszar bezpośredniego dostępu przy minimalnym obciążeniu zasobów kontroli poznawczej (w szczególności zasobów wykorzystywanych przez wspomniane funkcje zarządcze) albo zadanie wyraźnie obciążające zasoby ostatniego rodzaju przy jednoczesnym minimalnym zajęciu obszaru bezpośredniego dostępu. Takie badanie miałoby szansę pomóc w sformułowaniu praktycznych zaleceń dotyczących tego, jak skutecznie pozbyć się niepożądanych myśli.

\section{BIBLIOGRAFIA}

Abramowitz, J.S., Tolin, D.F., Street, G.P. (2001). Paradoxical effects of thought suppression: A meta-analysis of controlled studies. Clinical Psychology Review, 21, 683-703.

Anderson, M.C., Green, C. (2001). Suppressing unwanted memories by executive control. Nature, 410, 366-369.

Anderson, M.C., Huddleston, E. (2012). Towards a cognitive and neurobiological model of motivated forgetting. W: R.F. Belli (red.). True and False Recovered Memories (s. 53-120). New York: Springer.

Anderson, M.C., Levy, B.J. (2009). Suppressing unwanted memories. Current Directions in Psychological Science, 18, 189-194.

Bjork, E.L., Bjork, R.A., Anderson, M.C. (1998). Varieties of goal-directed forgetting. W: J.M. Golding, C.M. MacLeod (red.). Intentional Forgetting: Interdisciplinary Approaches (s. 103137). Mahwah, NJ: Lawrence Erlbaum Associates.

Conway, M.A., Harries, K., Noyes, J., Racsmány, M., Frankish, C.R. (2000). The disruption and dissolution of directed forgetting: Inhibitory control of memory. Journal of Memory and Language, 43, 409-430.

Duncan, J., Martens, S., Ward, R. (1997). Restricted attentional capacity within but not between sensory modalities. Nature, $387,808$.

Friedman, N.P., Miyake, A. (2017). Unity and diversity of executive functions: Individual differences as a window on cognitive structure. Cortex, 86, 186-204.

Friedman, N.P., Miyake, A., Young, S.E., DeFries, J.C., Corley, R.P., Hewitt, J.K. (2008). Individual differences in executive functions are almost entirely genetic in origin. Journal of Experimental Psychology: General, 137, 201-225. 
Hertel, P.T., Calcaterra, G. (2005). Intentional forgetting benefits from thought substitution. Psychonomic Bulletin and Review, 12, 484-489.

Konstantinou, N., Beal, E., King, J.R., Lavie, N. (2014). Working memory load and distraction: dissociable effects of visual maintenance and cognitive control. Attention, Perception, \& Psychophysics, 76, 1985-1997.

Lavie, N. (2010). Attention, distraction, and cognitive control under load. Current Directions in Psychological Science, 19, 143-148.

Lavie, N., Hirst, A., de Fockert, J.W., Viding, E. (2004). Load theory of selective attention and cognitive control. Journal of Experimental Psychology: General, 133, 339-354.

Levy, B.J., Anderson, M.C. (2008). Individual differences in the suppression of unwanted memories: The executive deficit hypothesis. Acta Psychologica, 127, 623-635.

Lin, Y., Wicker, F.W. (2007). A comparison of the effects of thought suppression, distraction and concentration. Behaviour Research and Therapy, 45, 2924-2937.

Luciano, J.V., González, S.A. (2007). Analysis of the Efficacy of Different Thought Suppression Strategies. International Journal of Psychology and Psychological Therapy, 7, 335-345.

Magee, J.C., Harden, K.P., Teachman, B.A. (2012). Psychopathology and thought suppression: A quantitative review. Clinical Psychology Review, 32, 189-201.

Macrae, C.N., Bodenhausen, G.V., Milne, A.B., Ford, R.L. (1997). On regulation of recollection: The intentional forgetting of stereotypical memories. Journal of Personality and Social Psycho$\log y, 72,709-719$.

Najmi, S., Wegner, D.M. (2008). Mental control: Thought suppression and psychopathology. W: A. Elliott (red.). Handbook of Approach and Avoidance Motivation (s. 447-459). Mahwah, NJ: Erlbaum.

Nęcka, E., Orzechowski, J., Szymura, B. (2006). Psychologia poznawcza. Warszawa: Wydawnictwo Naukowe PWN.

Nigg, J.T. (2017). Annual Research Review: On the relations among self-regulation, self-control, executive functioning, effortful control, cognitive control, impulsivity, risk-taking, and inhibition for developmental psychopathology. Journal of Child Psychology and Psychiatry, 58, 361-383.

Nixon, R.D.V., Cain, N., Nehmy, T., Seymour, M. (2009). The influence of thought suppression and cognitive load on intrusions and memory processes following an analogue stressor. $\mathrm{Be}$ havior Therapy, 40, 368-379.

Nixon, R.D., Rackebrandt, J. (2016). Cognitive Load Undermines Thought Suppression in Acute Stress Disorder. Behavior Therapy, 47, 388-403.

Norman, D.A., Bobrow, D.G. (1975). On data-limited and resource-limited processes. Cognitive Psychology, 7, 44-64.

Oberauer, K. (2006). Is the focus of attention in working memory expanded through practice? Journal of Experimental Psychology: Learning, Memory, and Cognition, 32, 197-214.

Oberauer, K., Bialkova, S. (2009). Accessing information in working memory: Can the focus of attention grasp two elements at the same time? Journal of Experimental Psychology: General, 138, 64-87.

Purdon, C. (1999). Thought suppression and psychopathology. Behaviour Research and Therapy, 37, 1029-1054.

Rachman, S., de Silva, P. (1978). Abnormal and normal obsessions. Behaviour Research and Therapy, 16, 233-248.

Rassin, E. (2005). Thought Suppression. Amsterdam: Elsevier.

Śpiewak, S. (2013). Rozgrzewanie uwagi - wyczerpywanie woli - uległość. Warszawa: Wydawnictwo Naukowe Scholar.

Sheard, E.D., MacLeod, C.M. (2005). List method directed forgetting: return of the selective rehearsal account. W: N. Ohta, C.M. MacLeod, B. Uttl (red.). Dynamic Cognitive Processes (s. 219-248). Tokyo: Springer-Verlag. 
Ward, A., Mann, T. (2000). Don't mind if I do: disinhibited eating under cognitive load. Journal of Personality and Social Psychology, 78, 753-763.

Wegner, D.M. (1994). Ironic processes of mental control. Psychological Review, 101, 34-52.

Wegner, D.M. (2009). How to think, say, or do precisely the worst thing for any occasion. Science, $325,48-50$.

Wegner, D.M., Erber, R. (1992). The hyperaccessibility of suppressed thoughts. Journal of Personality and Social Psychology, 63, 903-912.

Wegner, D.M., Erber, R., Zanakos, S. (1993). Ironic processes in the mental control of mood and mood-related thought. Journal of Personality and Social Psychology, 65, 1093-1104.

Wegner, D.M., Schneider, D.J., Carter, S., White, T. (1987). Paradoxical effects of thought suppression. Journal of Personality and Social Psychology, 53, 5-13.

Wenzlaff, R.M., Bates, D.E. (2000). The relative efficacy of concentration and suppression strategies of mental control. Personality and Social Psychology Bulletin, 26, 1200-1212.

Wenzlaff, R.M., Wegner, D.M. (2000). Thought suppression. Annual Review of Psychology, 51, 59-91.

Wickens, C.D., Kessel, C. (1980). The processing resource demands of failure detection in dynamic systems. Journal of Experimental Psychology: Human Perception and Performance, 6, 546-577. 